\title{
ASSOCIATION OF TRINUCLEOTIDE-REPEAT- CONTAINING 9 (TNRC9) SNP WITH THE RISK OF BREAST CANCER IN EGYPTIANS
}

\author{
Manal A Safan ${ }^{1}$ and Alaa A El-Sisi ${ }^{2}$ \\ ${ }^{1}$ Medical Biochemistry and ${ }^{2}$ Surgical Oncology Departments \\ Faculty of Medicine, Menoufia University, Egypt
}

Received 9/5/2016 - Accepted 19/6/2016

\begin{abstract}
Breast cancer is a heterogeneous disorder for which the underlying genetic basis remains unclear. The current study was conducted to evaluate the possible association between trinucleotide-repeatcontaining 9 (TNRC9) genetic variants and breast cancer risk in Egyptian women. Genotyping of the rs 12443621 polymorphism of the TNRC9 gene by real time PCR (RT-PCR) on 100 female breast cancer patients and 80 healthy female controls was done. Breast cancer patients have significantly decreased age at menarche compared to control. Breast feeding and parity are associated with reduced breast cancer risk. The homozygous GG genotype and $G$ allele were more frequent in the breast cancer group than in control subjects. The GG genotype frequency was associated with 2.8 times higher risk of breast cancer than AA genotype, also the $G$ allele was associated with 1.9 times higher risk of breast cancer than A allele. The distribution of the TNRC9 rs12443621 polymorphism was significantly associated with both estrogen and progesterone receptor status. The combined AG and GG genotypes were not significantly associated with the presence of metastasis and $\mathrm{Her}_{2} /$ neu status $(\mathrm{P}=0.89$ and 0.49 , respectively). From this study, it could be concluded that, a significant association was found between the GG genotype of TNRC9 rs12443621 and elevated breast cancer risk and signifies the TNRC9 rs12443621 G allele as being a potential risk factor for breast cancer. Further larger population-based studies are needed to confirm the prognostic value of this polymorphism in Egyptian women.
\end{abstract}

* Correspondence Author (e mail: Manal A Safan @hotmail.com) 
Key words: TNRC9 gene, Her2-neu, real time PCR, breast cancer. Corresponding author: manalsafan1@ hotmail.com

\section{INTRODUCTION}

Breast cancer is one of the leading causes of cancer morbidity and mortality among women worldwide (Simonsson et al., 2016), it is the most common cancer diagnosed among women worldwide accounting for $29 \%$ of the total new cancer cases. It is also the second leading cause of cancer death among women after lung cancer, accounting for $15 \%$ of the total cancer deaths (Siegel et al., 2014). In Egypt, breast cancer represents the most common type of cancer among Egyptian women, representing $18.9 \%$ of total cancer cases (Motawi et al., 2016).

Breast cancer is a multifactorial disease influenced by complex interactions between genetic, environmental, and lifestyle factors. In recent years, variations in a single base pair in the DNA sequence (single-nucleotide polymorphisms, SNPs) have been widely studied in cancer research (Wang et al., 2016).

A significant advancement has been made in understanding the genetic susceptibility to breast cancer. To further identify novel susceptibility alleles associated with breast cancer, genome-wide association studies (GWAS) have been performed. One of these studies identified trinucleotide-repeat-containing 9 (TNRC9, also known as TOX3) as a novel loci with consistent evidence of association with breast cancer (Chen et al., 2016).

Trinucleotide repeat-containing 9 (TNRC9) is a gene located at chromosome 16q12. TNRC 9 is a nuclear protein containing a nuclear localization signal and a high mobility group-box domain that can modify chromatin structure, suggesting its possible role as transcription factor. Genetic variation in TNRC9 gene is a newly described risk factor for breast cancer and it has been implicated in breast cancer metastasis ( $\mathbf{L i}$ et al., 2009). Previous studies on the association between TNRC9 polymorphisms and breast cancer risk provide inconclusive results (Chen et al., 2011).

In view of the previous observations, the aim of the present study is to evaluate the association of TNRC9 rs12443621 polymorphism with breast cancer risk and with the clinicopathological features of breast cancer in Egyptians. 


\section{Subjects:}

\section{MATERIALS AND METHODS}

This study was carried out at the Medical Biochemistry and Surgical Oncology departments, Faculty of Medicine, Menoufia University. 180 female subjects were enrolled in the study, they were classified into two groups: group I included 100 preoperative breast cancer patients, who were clinically diagnosed with breast cancer and confirmed by mammography and histopathological examination of surgical biopsies. All patients had unilateral primary breast cancer, with no family history of the disease. No patients received antihormonal treatment, chemotherapy or radiotherapy prior to participation in the study. Group II included 80 age-matched normal healthy females served as a control group, with no evidence of any personal or family history of cancer or other chronic illness; they had no palpable breast masses and received no contraceptives. The study was approved by ethical committee of Faculty of Medicine, Menoufia University. A written informed consent was obtained from all subjects included in the study.

All subjects were submitted to the following: full history taking (including family history of breast cancer), general and local clinical examination, radiological investigations (ultrasound and mammography). Analysis of the genetic polymorphisms of the TNRC 9 (rs12443621) was performed using real time PCR technique.

\section{Methods:}

Specimen collection: $5 \mathrm{ml}$ of venous blood was withdrawn preoperatively, after 10 hours overnight fasting, and was transferred into EDTA (ethylene diamine tetra acetic acid) containing tube and genomic DNA was extracted from the peripheral whole blood with the Qiagen extraction kit (Hilden, Germany). DNA eluted in buffer AE was stored at $-20 \mathrm{C}^{\circ}$ for further PCR procedure.

\section{TaqMan real time PCR genotyping assay:}

Genotyping of the rs12443621 polymorphism of the TNRC9 gene was carried out by real time PCR (RT-PCR) by allele discrimination using TaqMan SNP Genotyping on Applied Biosystems 7500 Real-Time PCR System, with TaqMan SNP Genotyping assay kit supplied by (Applied Biosystem, USA, 2012). During TaqMan SNP Genotyping Assay experiment, DNA polymerase from the TaqMan Universal PCR master mixture amplifies target DNA using sequence-specific primers 
supplied with the kit. TaqMan Two fluorogenic minor groove binder probes provide a fluorescence signal for allelic discrimination using the dyes 6-carboxyfluorescein (FAM; excitation, $494 \mathrm{~nm}$ ) and VIC (excitation, $538 \mathrm{~nm}$ ) which are easily differentiated in RT-PCR system.

The reaction mixture $(25 \mu \mathrm{l}$ total volume per single well reaction) containing $12.5 \mu \mathrm{l}$ of TaqMan $2 \mathrm{X}$ universal master mix (Applied Biosystems, USA, 2012), $1.25 \mu$ of $20 \times$ SNP Genotyping Assay [which contains Forward and reverse sequences of primers and TaqMan Probe (VIC/FAM) dye mix], [CGTTTTATATGCATTAGGCCTGGCA [A/G] TGAACTTGAGG AGGTATTACTATC], $6.25 \mu \mathrm{l}$ of RNase- and DNase-free water and 5 $\mu l$ of DNA template. DNase-free water used as negative control was included in each assay run. The cycling conditions include a $10 \mathrm{~min}$ of pre-denaturation at $95^{\circ} \mathrm{C}$ (AmpliTaq Gold DNA polymerase activation), followed by 45 cycles with a fast denaturation at $95^{\circ} \mathrm{C}$ for 15 seconds, annealing of the TaqMan probes to its complementary sequence and extension of the primers by AmpliTaq Gold DNA polymerase for $1 \mathrm{~min}$ at $60{ }^{\circ} \mathrm{C}$. The 96-well PCR plates were read on an Applied Biosystems 7500 Real-Time PCR System with endpoint analysis mode of the SDS v1.3.1, which uses the fluorescence measurements made during the plate read to plot fluorescence $(\mathrm{Rn})$ values based on the signals from each well. Three genotypes for the studied polymorphism were detected; normal homozygous, mutant homozygous and mutant heterozygous. Allelic discrimination was performed by inspecting the fluorescence from the probe.

\section{Statistical analysis:}

Statistical analysis was performed using the SPSS 20 software package. Chi-square test is used to study association between two qualitative variables. Fisher exact test was employed when sample sizes are small. The difference between 2 groups was performed by student's t-test for parametric variables. Odds ratio, describe the probability that people who are exposed to a certain factor will have a disease compared to people who are not exposed to this factor. A Pvalue of $<0.05$ was considered statistically significant.

\section{RESULTS}

The results of the present study showed that breast cancer patients have significantly decreased age at menarche compared with control 
(14.2 \pm 0.3 vs. $15.5 \pm 0.4$, respectively). Breast-feeding and parity are associated with reduced breast cancer risk $(\mathrm{P}<0.05)$, however, no significant difference was found between control and breast cancer groups regarding age at diagnosis $(49.5 \pm 2.3$ vs. 50.1 2.5 , respectively), age at menopause ( $48.9 \pm 3.2$ vs. $49.7 \pm 2.5$, respectively), family history of breast cancer or menopausal status $(\mathrm{P}>0.05)$. The most common tumor histology type in patients was ductal carcinoma accounting for $77 \%$, compared with $23 \%$ lobular carcinoma. Only nine patients $(9 \%)$ presented at histological grade 1 , and grade 2 and 3 accounted for $71 \%$ and $20 \%$ of patients, respectively. The majority of patients (82\%) have tumor size T1-T2. $28 \%$ and $34 \%$ of breast cancer patients show LN invasion and have distant metastasis, respectively. The breast cancer patients consisted of (42\%) ER-negative tumors and (58\%) ER-positive tumors; $40 \%$ of patients had PR-negative tumors and $60 \%$ had PR-positive tumors; and $66 \%$ of patients had HER2negative tumors and 34\% had HER2-positive tumors (table 1). There was a significant difference in the genotype and allele frequency distribution of TNRC9 rs12443621 SNP in breast cancer patients and control subjects. The frequency of TNRC9 rs12443621 genotypes AA, $\mathrm{AG}$ and GG in patient group was $21 \%, 19 \%$ and $60 \%$ in comparison with $42.5 \%, 13.75 \%$ and $43.75 \%$ in control group, respectively. A significant association was found between TNRC 9 rs12443621 and breast cancer risk, specifically, the $\mathrm{GG}$ genotype $(\mathrm{OR}=2.8,95 \% \mathrm{CI}=$ 1.40-5.51), combined $\mathrm{AG}$ and $\mathrm{GG}$ genotypes $(\mathrm{OR}=2.8,95 \% \mathrm{CI}=1.45$ 5.35) and $\mathrm{G}$ allele $(\mathrm{OR}=2.2,95 \% \mathrm{CI}=1.44-3.42)$ (table 2). The polymorphism was significantly associated with both $\mathrm{ER}(\mathrm{P}=0.013)$ and $\mathrm{PR}$ expression $(\mathrm{P}=0.025)$ as manifested by a higher distribution of combined $A G$ and $G G$ genotypes in ER negative than in ER positive patients $(91.4 \%$ versus $61.9 \%)$ and in PR negative than in PR positive patients $(86.7 \%$ versus $67.5 \%)$. On the other hand, the AA genotype was notably associated with positive ER and PR status whereby AA carriers represented $38.1 \%$ of ER positive patients and $32.5 \%$ of PR positive patients versus $8.6 \%$ of ER negative patients and $13.3 \%$ of PR negative patients. The combined AG and GG genotypes were significantly associated with the presence of ER-negative tumor and PR-negative tumor $(\mathrm{OR}=3.6,95 \% \mathrm{CI}=1.32-10.08, \mathrm{p}=0.013$ and $\mathrm{OR}=$ $3.1,95 \% \mathrm{CI}=1.16-8.47, \mathrm{p}=0.025$, respectively), however, there was no significant association with the presence of metastasis and Her2/neu status ( $\mathrm{P}=0.89$ and 0.49 , respectively) (table 3 ). 
Table 1: Demographic and clinical characteristics of the studied groups

\begin{tabular}{|c|c|c|}
\hline Characteristics & $\begin{array}{c}\text { Control group } \\
(n=80)\end{array}$ & $\begin{array}{l}\text { Breast cancer } \\
\text { group }(n=100)\end{array}$ \\
\hline Age at diagnosis (years): mean \pm SD & $49.5 \pm 2.3$ & $50.1 \pm 2.5^{\#}$ \\
\hline Age at menarche (years): mean \pm SD & $15.5 \pm 0.4$ & $14.2 \pm 0.3 * \#$ \\
\hline Age at menopause (years): mean \pm SD & $48.9 \pm 3.2$ & $49.7 \pm 2.5^{\#}$ \\
\hline Family history of breast cancer: $n(\%)$ & & \\
\hline No & $78(97.5)$ & $96(96)^{\mathrm{II}}$ \\
\hline Yes & $2(2.5)$ & $3(3)$ \\
\hline Menopausal status: $\mathbf{n}(\%)$ & & \\
\hline Premenopausal & 39 (48.75) & $48(48)^{\$}$ \\
\hline Postmenopausal & $41(51.25)$ & $52(52)$ \\
\hline Parity: n (\%) & & \\
\hline 0 & $3(3.75)$ & $9(9) *$ II \\
\hline 1-2 & $22(27.50)$ & $42(42)$ \\
\hline$\geq \mathbf{3}$ & $55(68.75)$ & $49(49)$ \\
\hline Breast feeding: $\mathbf{n}(\%)$ & & \\
\hline No & $5(6.25)$ & $17(17)^{* \$}$ \\
\hline Yes & 75 (93.75) & $83(83)$ \\
\hline Histological type: n (\%) & & \\
\hline Ductal carcinoma & - & 77 (77) \\
\hline Lobular carcinoma & & $23(23)$ \\
\hline Histological grade: $\mathbf{n}(\%)$ & & \\
\hline 1 & - & $9(9)$ \\
\hline 2 & & $71(71)$ \\
\hline 3 & & $20(20)$ \\
\hline Tumour size: $\mathbf{n}(\%)$ & & \\
\hline$T_{1}-T_{2}$ & - & $82(82)$ \\
\hline $\mathbf{T}_{3}-\mathbf{T}_{4}$ & & $18(18)$ \\
\hline LN invasion: $n(\%)$ & & \\
\hline Negative & - & $72(72)$ \\
\hline Positive & & $28(28)$ \\
\hline Metastasis: n (\%) & & \\
\hline Negative & ـ & $66(66)$ \\
\hline Positive & & 34 (34) \\
\hline Estrogen receptor status: n (\%) & & \\
\hline Negative & - & $42(42)$ \\
\hline Positive & & $58(58)$ \\
\hline Progesterone receptor status: $n(\%)$ & & \\
\hline Negative & - & $40(40)$ \\
\hline Positive & & $60(60)$ \\
\hline Her $_{2} /$ neu: n (\%) & & \\
\hline Negative & - & $66(66)$ \\
\hline Positive & & 34 (34) \\
\hline
\end{tabular}

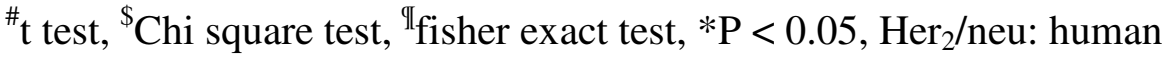
epidermal receptor 2 
Table 2: Genotype distribution and allele frequency of TNRC9 rs12443621 polymorphism among the studied groups

\begin{tabular}{|c|c|c|c|c|c|c|}
\hline \multirow[t]{2}{*}{$\begin{array}{c}\text { TNRC9 } \\
\text { rs12443621 }\end{array}$} & \multicolumn{2}{|c|}{$\begin{array}{l}\text { Control group } \\
\qquad(\mathbf{n}=\mathbf{8 0})\end{array}$} & \multicolumn{2}{|c|}{$\begin{array}{c}\text { Breast cancer } \\
\text { group } \\
(\mathrm{n}=\mathbf{1 0 0})\end{array}$} & \multirow[t]{2}{*}{$* \mathbf{P}$} & \multirow[t]{2}{*}{$\begin{array}{c}\text { OR } \\
(95 \% \mathrm{CI})\end{array}$} \\
\hline & No & $\%$ & No & $\%$ & & \\
\hline Genotypes: & & & & & \multirow{7}{*}{0.008} & \multirow{7}{*}{$\begin{array}{c}1.0 \\
2.7(1.11-7.02) \\
2.8(1.40-5.51) \\
2.8(1.45-5.35)\end{array}$} \\
\hline & 34 & 42.5 & 21 & 21 & & \\
\hline AG & 11 & 13.75 & 19 & 19 & & \\
\hline GG & 35 & 43.75 & 60 & 60 & & \\
\hline \multirow[t]{3}{*}{$\mathbf{A G + G G}$} & 46 & 57.5 & 79 & 79 & & \\
\hline & \multicolumn{2}{|c|}{$(n=160)$} & \multicolumn{2}{|c|}{$(\mathbf{n}=\mathbf{2 0 0})$} & & \\
\hline & No & $\%$ & No & $\%$ & & \\
\hline $\begin{array}{l}\text { Alleles: } \\
\text { A } \\
\text { G }\end{array}$ & $\begin{array}{l}79 \\
81\end{array}$ & $\begin{array}{l}49.4 \\
50.6\end{array}$ & $\begin{array}{c}61 \\
139\end{array}$ & $\begin{array}{l}30.5 \\
69.5\end{array}$ & 0.0003 & $\begin{array}{c}1.0 \\
2.2(1.44-3.42)\end{array}$ \\
\hline
\end{tabular}

*Chi square test, OR: odd's ratio

Table 3: Association between polymorphism and clinical characteristics of breast cancer patients

\begin{tabular}{|c|c|c|c|c|c|c|}
\hline \multirow{3}{*}{ Characteristics } & \multicolumn{4}{|c|}{$\begin{array}{c}\text { Genotypes among patients } \\
(\mathbf{n}=\mathbf{1 0 0 )}\end{array}$} & \multirow{3}{*}{$* \mathbf{P}$} & \multirow{3}{*}{$\begin{array}{c}\text { OR } \\
(95 \% \mathrm{CI})\end{array}$} \\
\hline & \multicolumn{2}{|c|}{$\mathbf{A A}(\mathbf{n}=21)$} & \multicolumn{2}{|c|}{ AG+GG (n=79) } & & \\
\hline & No & $\%$ & No & $\%$ & & \\
\hline $\begin{array}{l}\text { Age at diagnosis (years): } \\
<50(\mathrm{n}=31) \\
\geq 50(\mathrm{n}=69)\end{array}$ & $\begin{array}{c}4 \\
17\end{array}$ & $\begin{array}{l}12.9 \\
24.6\end{array}$ & $\begin{array}{l}27 \\
52\end{array}$ & $\begin{array}{l}87.1 \\
75.4\end{array}$ & 0.19 & $\begin{array}{c}1.0 \\
0.45(0.14-1.48)\end{array}$ \\
\hline $\begin{array}{l}\text { Menopausal status: } \\
\text { Premenopausal }(n=48) \\
\text { Postmenopausal }(n=52) \\
\end{array}$ & $\begin{array}{c}7 \\
14 \\
\end{array}$ & $\begin{array}{l}14.6 \\
26.9\end{array}$ & $\begin{array}{l}41 \\
38 \\
\end{array}$ & $\begin{array}{l}85.4 \\
73.1\end{array}$ & 0.14 & $\begin{array}{c}1.0 \\
0.46(0.17-1.27) \\
\end{array}$ \\
\hline $\begin{array}{l}\text { Tumour size: } \\
T_{1}-T_{2}(n=82) \\
T_{3}-T_{4}(n=18)\end{array}$ & $\begin{array}{r}17 \\
4\end{array}$ & $\begin{array}{l}20.7 \\
22.2\end{array}$ & $\begin{array}{l}65 \\
14\end{array}$ & $\begin{array}{l}79.3 \\
77.8\end{array}$ & 0.89 & $\begin{array}{c}1.0 \\
0.92(0.27-3.14)\end{array}$ \\
\hline $\begin{array}{l}\text { LN invasion: } \\
\text { Negative }(n=72) \\
\text { Positive }(n=28)\end{array}$ & $\begin{array}{c}15 \\
6\end{array}$ & $\begin{array}{l}20.8 \\
21.4\end{array}$ & $\begin{array}{l}57 \\
22\end{array}$ & $\begin{array}{l}79.2 \\
78.6\end{array}$ & 0.95 & $\begin{array}{c}1.0 \\
0.96(0.33-2.80)\end{array}$ \\
\hline $\begin{array}{l}\text { Metastasis: } \\
\text { Negative }(n=66) \\
\text { Positive }(n=34)\end{array}$ & $\begin{array}{c}15 \\
6\end{array}$ & $\begin{array}{l}22.7 \\
17.6\end{array}$ & $\begin{array}{l}51 \\
28\end{array}$ & $\begin{array}{l}77.3 \\
82.4\end{array}$ & 0.89 & $\begin{array}{c}1.0 \\
1.37(0.48-3.93)\end{array}$ \\
\hline $\begin{array}{l}\text { ER status: } \\
\text { Negative }(n=42) \\
\text { Positive }(n=58) \\
\end{array}$ & $\begin{array}{c}5 \\
16 \\
\end{array}$ & $\begin{array}{c}8.6 \\
38.1 \\
\end{array}$ & $\begin{array}{l}53 \\
26 \\
\end{array}$ & $\begin{array}{l}91.4 \\
61.9 \\
\end{array}$ & 0.013 & $\begin{array}{c}1.0 \\
3.6(1.32-10.08)\end{array}$ \\
\hline $\begin{array}{l}\text { PR status: } \\
\text { Negative }(n=40) \\
\text { Positive }(n=60)\end{array}$ & $\begin{array}{c}8 \\
13\end{array}$ & $\begin{array}{l}13.3 \\
32.5\end{array}$ & $\begin{array}{l}52 \\
27\end{array}$ & $\begin{array}{l}86.7 \\
67.5\end{array}$ & 0.025 & $\begin{array}{c}1.0 \\
3.1(1.16-8.47)\end{array}$ \\
\hline $\begin{array}{l}\text { Her } 2 / \text { neu: } \\
\text { Negative }(n=66) \\
\text { Positive }(n=34)\end{array}$ & $\begin{array}{c}15 \\
6\end{array}$ & $\begin{array}{l}22.7 \\
17.6\end{array}$ & $\begin{array}{l}51 \\
28\end{array}$ & $\begin{array}{l}77.3 \\
82.4\end{array}$ & 0.49 & $\begin{array}{c}1.0 \\
1.45(0.51-4.15)\end{array}$ \\
\hline
\end{tabular}

*Chi square test, OR: odd's ratio, ER: Estrogen receptor, PR: Progesterone receptor. 


\section{DISCUSSION}

Genetic studies have provided insight into various diseases, including cancers. Understanding the associations between different genes and cancers can improve prevention, treatment, and prognosis estimation. Genome-wide association studies (GWAS) have revealed many genetic markers of different cancers (Wang et al., 2016).

In familial linkage studies, several gene mutations confer increased susceptibility to breast cancer (Walsh and King, 2007), including breast cancer 1 gene (BRCA1), BRCA2; however, these causative mutations explain only approximately $25 \%$ of the familial risk and almost 5\% of breast cancer incidence (Pharoah et al., 2004). Therefore, other genes/loci might have significant associations with breast cancer risk and might contribute to the remaining $75 \%$ of the risk. Previous studies of specific candidate single nucleotide polymorphisms (SNPs) have revealed a number of novel genetic susceptibility variants and loci, including FGFR2, TOX3/LOC643714, LSP1, MAP3K1, chromosome 8q24, and CASP8, which were independently associated with an increased risk of breast cancer (Reeves et al., 2010).

The rs12443621 SNP of the TNRC9 gene (also named TOX3) is located at chromosome 16q12. The function of TNRC9 is still unclear, but a previous study conducted by Shan et al., (2012) has reported that TNRC9 down-regulates BRCA1 expression through altering the methylation status of its promoter and promotes breast cancer aggressiveness.

Other risk factors for breast cancer may include population differences that vary by ethnicity, family history, menopausal status and each of estrogen receptor (ER), progesterone receptor (PR), or human epidermal growth factor receptor 2 (HER2) tumor statuses.

In this breast cancer case-control study among Egyptian women, the genotype distribution and allele frequency of TNRC9 gene polymorphism rs12443621 was compared between breast cancer patients and normal female subjects. Also, the association between the studied SNP and clinicopathological features of breast cancer was investigated.

The present study revealed that early age at menarche is associated with increased breast cancer risk, whereas breast-feeding and parity are associated with reduced breast cancer risk. Multiple studies have 
examined the relationship between various reproductive factors and breast cancer risk, but the results are somewhat inconsistent. The inconsistency in research findings on the association between reproductive factors and breast cancer risk may be attributed to the fact that breast cancer is a complicated disease affected by many factors including genetic, environmental, and economic conditions as well as lifestyle (Nagata et al., 1995; Stuver et al., 1997 and do Carmo et al., 2012).

In the current study, a significant difference in the distribution of the TNRC9 rs12443621 genotypes and alleles was observed between breast cancer patient and controls ( $\mathrm{P}=0.008$ and 0.027 , respectively). A significant association was found between TNRC9 rs12443621 and breast cancer risk, specifically, the GG genotype $(\mathrm{OR}=2.8,95 \% \mathrm{CI}=$ 1.40-5.51), combined $\mathrm{AG}$ and $\mathrm{GG}$ genotypes $(\mathrm{OR}=2.8,95 \% \mathrm{CI}=1.45$ 5.35) and $\mathrm{G}$ allele $(\mathrm{OR}=1.9,95 \% \mathrm{CI}=1.23-2.95)$. These data implicate TNRC9 rs12443621 as a possible contributor to breast tumorigenesis, and suggest a role for the $G$ allele in the increased expression of TNRC9 and higher susceptibility to breast cancer.

The association between TNRC9 polymorphisms and breast cancer risk remains controversial. These results are in agreement with a previous Swedish study conducted by Butt et al., (2012), In contrast to our results, a previous study among Tunisian women (Shan et al., 2012) and a meta-analysis in 2011 found that TNRC9 rs12443621 polymorphism was not significantly correlated with breast cancer risk (Chen et al., 2011). The reason for the controversial findings regarding the association between TRNC9 rs12443621 and breast cancer risk is difficult to be explained but could be related to the different patient populations, numbers of samples and/or ethnic variations or may be due to multifaceted characteristics of breast cancer.

In this study, the distributions of the TNRC9 rs12443621 genotypes were compared in relation to the different clinicopathological variables associated with breast cancer. The polymorphic form AG and GG of TNRC9 rs12443621 polymorphism was significantly associated with both ER $(\mathrm{P}=0.013)$ and $\mathrm{PR}$ expression $(\mathrm{P}=0.025)$, on the other hand, the AA genotype was notably associated with negative ER and PR status. The current study also revealed that the combined AG and GG genotypes were associated with the presence of metastasis and $\mathrm{Her}_{2} /$ neu status $(\mathrm{OR}=1.37$ and 1.45 , respectively), but 
it doesn't reach a statistical significance. Such findings highlight the potential prognostic values of TNRC9 rs12443621 gene polymorphism in breast cancer. These results are in agreement with that of Shan et al., (2013) who revealed that TNRC9 gene is amplified and overexpressed in breast cancer, particularly in advanced stages, showing a significant association between TNRC9 gene amplification and reduction in disease-free and metastasis-free survival rates, suggesting that TNRC9 could be involved in the onset of aggressive forms of breast cancer.

A previous study in the Tunisian population highlighted clinical and biological differences in breast cancer in Arab women compared to Europeans (more aggressive forms of breast cancer in Arab populations). In addition, Arab populations greatly differ from European and Asian populations by lifestyle, reproductive behavior, and environmental exposure. Thus, new GWAS in women of Arab ancestry may promise to reveal new causal variants and are needed to fully uncover the genetic basis for breast cancer susceptibility in Arab population (Chalabi et al., 2008).

Conclusion:

From this study, it could be concluded that a significant association was found between the GG genotype of TNRC9 rs12443621 and elevated breast cancer risk and signifies the $G$ allele as being a potential risk factor for breast cancer, which may explain one of the complex biological mechanisms of breast cancer. Further larger population-based studies are needed to confirm the prognostic value of this polymorphism in Egyptian women.

\section{REFERENCES}

Butt S, Harlid S, Borgquist S, Ivarsson M, Landberg G, Dillner J, Carlson J and Manjer J (2012): Genetic predisposition, parity, age at first childbirth and risk of breast cancer. BMC Res Notes. 7(5):414-424.

Chalabi N, Bernard-Gallon DJ, Bignon YJ; Breast Med Consortium, Kwiatkowski F, Agier M, Vidal V, Laplace-Chabaud V, Sylvain-Vidal V, Bertholet V, De Longueville F, Lacroix M, Leclercq G, Remacle J, Sibille C, Zammateo N, Ben Jaafar N, Sefiani A, Ouldim K, Mégarbané K, Jalkh N, Mahfoudh W, Troudi W, Ben Ammar-El Gaïed $A$ and Chouchane $L$ (2008): Comparative clinical and transcriptional profiles of breast cancer between French and South Mediterranean patients show minor but significant biological differences. Cancer Genomics Proteomics. 5(5): 253-561. 
Chen MB, Wu XY, Shen W, Wei MX, Li C, Cai B, Tao GQ and Lu PH (2011): Association between polymorphisms of trinucleotide repeat containing 9 gene and breast cancer risk: evidence from 62,005 subjects. Breast Cancer Res Treat. 126(1):177-183.

Chen Y, Shi C and Guo Q (2016): TNRC9 rs12443621 and FGFR2 rs2981582 polymorphisms and breast cancer risk. World J Surg Oncol. 14(1):50-55.

do Carmo Franca-Botelho A, Ferreira MC, Franca JL, Franca EL and Honorio Franca AC (2012): Breast feeding and its relationship with reduction of breast cancer: a review. Asian Pac J Cancer Prev. 13(11):53275332.

Li L, Zhou $X$, Huang $Z$, Liu $Z$, Song $M$ and Guo $Z$ (2009): TNRC9/LOC643714 polymorphisms are not associated with breast cancer risk in Chinese women. Eur J Cancer Prev. 18(4):285-90.

Motawi TM, Sadik NA, Shaker OG, EI Masry MR and Mohareb F (2016): $\quad$ Study of microRNAs 21/221 as potential breast cancer biomarkers in Egyptian women. Gene. pii: S0378-1119(16)00104-9.

Nagata C, Hu YH and Shimizu H (1995): Effects of menstrual and reproductive factors on the risk of breast cancer: meta-analysis of the casecontrol studies in Japan. Jpn J Cancer Res. 86(10):910-915.

Pharoah PD, Dunning AM, Ponder BA and Easton DF (2004): Association studies for finding cancersusceptibility genetic variants. Nat Rev Cancer. 4(11):850-860.

Reeves GK, Travis RC, Green J, Bull D, Tipper S, Baker K, Beral V, Peto R, Bell J, Zelenika D, Lathrop M; Million Women Study Collaborators (2010): Incidence of breast cancer and its subtypes in relation to individual and multiple low penetrance genetic susceptibility loci. JAMA. 304(4):426-434.

Shan J, Dsouza SP, Bakhru S, Al-Azwani EK, Ascierto ML, Sastry KS, Bedri S, Kizhakayil D, Aigha II, Malek J, Al-Bozom I, Gehani S, Furtado S, Mathiowitz E, Wang E, Marincola FM and Chouchane L (2013): TNCR9 downregulates BRCA1 expression and promotes breast cancer aggressiveness. Cancer Res. 73(9):2840-2849.

Shan J, Mahfoudh W, Dsouza SP, Hassen E, Bouaouina N, Abdelhak S, Benhadjayed A, Memmi H, Mathew RA, Aigha II, Gabbouj S, Remadi Y and Chouchane L (2012): Genome-Wide Association Studies (GWAS) breast cancer susceptibility loci in Arabs: susceptibility and prognostic implications in Tunisians. Breast Cancer Res Treat. 135(3):715724.

Siegel R, Ma J, Zou Z and Jemal A (2014): Cancer statistics, 2014. CA Cancer J Clin. 64(1):9-29. 
Simonsson M, Veerla S, Markkula A, Rose C, Ingvar C and Jernström H (2016): CYP1A2 - a novel genetic marker for early aromatase inhibitor response in the treatment of breast cancerpatients. BMC Cancer. $31 ; 16(1): 256$.

Stuver SO, Hsieh CC, Bertone E and Trichopoulos D (1997): The association between lactation and breast cancer in an international casecontrol study: a re-analysis by menopausal status. Int J Cancer.71(2):166169.

Walsh T and King MC (2007): Ten genes for inherited breast cancer. Cancer Cell. 11(2):103-105.

Wang M, Wang X, Fu SW, Liu X, Jin T, Kang H, Ma X, Lin S, Guan H, Zhang S, Liu K, Dai C, Zhu $Y$ and Dai $Z$ (2016): Singlenucleotide polymorphisms in PSCA and the risk of breast cancer in a Chinese population. Oncotarget. doi: 10.18632/oncotarget.8491.

$$
\begin{aligned}
& \text { دراسة العلاقة بين تعدد الأثكال الجينية لجين ثلاثي النوكليوتيد المتكرر-9 وخطر الاصابة }
\end{aligned}
$$

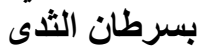

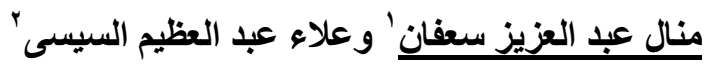

$$
\begin{aligned}
& \text { قسمى 'الكيمياء الحيوية الطبية ، 'جر احة الأورام كلبة الطب- جامعة المنوفية }
\end{aligned}
$$

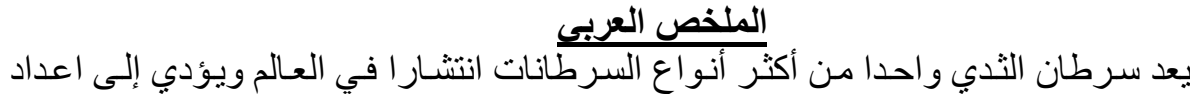

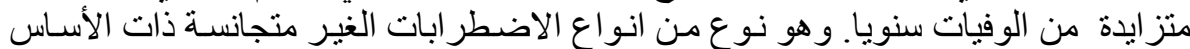

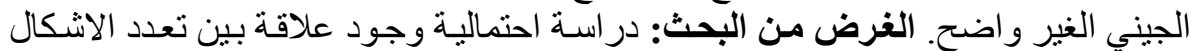

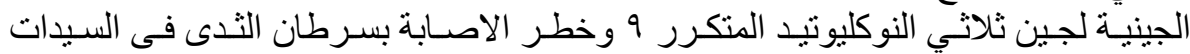

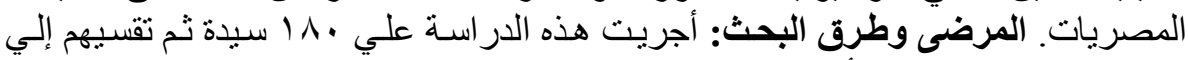

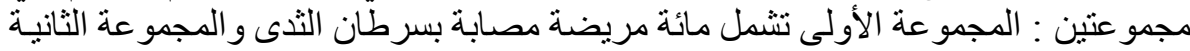

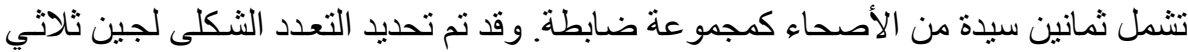

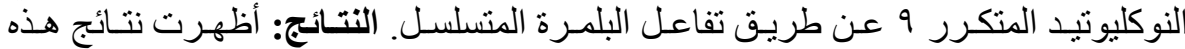

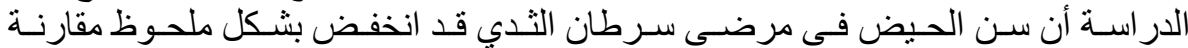

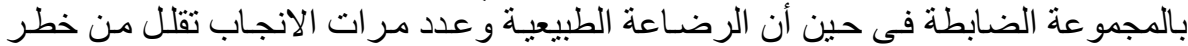

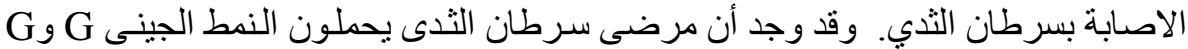

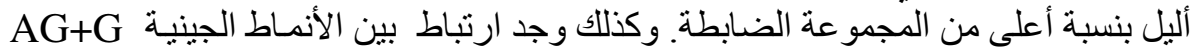

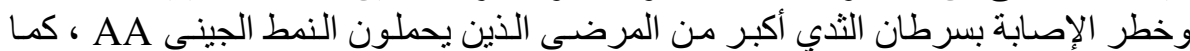

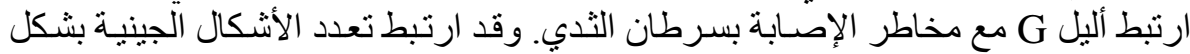

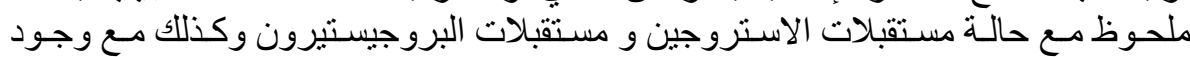

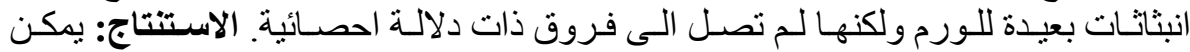

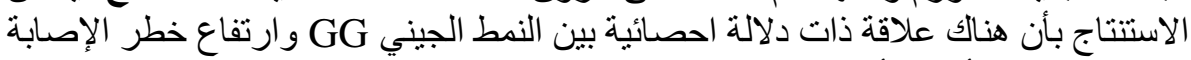

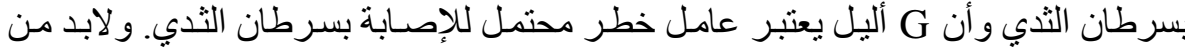

$$
\begin{aligned}
& \text { اجر اء در اسات على عدد أكبر من المرضى التئ لتأكيد هذه النتائج . }
\end{aligned}
$$

